\title{
CHILDREN'S DRAWING AS AN ART SCHEME FOR MODERN ART
}

\author{
Bozena Supsakova \\ Prof. Dr. PhD. Faculty of Education, Catholic University in Ruzomberok, Slovakia, \\ supsakova@gmail.com
}

\begin{abstract}
The period when the child's drawing was considered only some kind of doodling is over. A different look, different view on the child's artistic expression is nowadays, to a certain extent, also formed by the new art styles. We have in mind the art of the avant-garde, which in its essence, rejects the illusionist principle of reality approximation. That is why nowadays it is very interesting to study the symbol and its significance in fine art. Also to explore the child's artistic creation and to compare how the symbol is formed, how its meaning is formed, how the meaning is transformed into the context of its formation. It is also interesting who creates the sense and where the meaning is located. For us, the important role is played by a graphic symbol, which comprises all symbolizing or substitution qualities having their visual form in the shape of a line, surface, or in the system of visual tracks. The graphic symbol, which is located between the word and the picture, is irreplaceable. Their common feature is the graphic similarity, similarity purely accidental; on the other hand, semantic or meaningful value and concrete shapes significantly differ. Many signs, symbols, diagrams, and metaphors are symptomatic for mythology and its stories, as well as for the art of today. Contemporary art, in many respects, is close to the world of the child's drawing. The reason is that it does not attempt the accurate reproduction of phenomena that their authors meet daily. For contemporary artists, there is an importance of reflection, mood, feeling, a materialization of their inner world, which reacts to the world around them. The child, as well, through their symbols, tries to give a reference on themselves, and on what is around them. As the myth portrays the picture of the world through the symbols, also the child communicates with the surrounding environment. History of fine art and concerning culture document that the child's drawing has always been, and further on remains an inspiration for many masters of fine art. In the era of romanticism, the child's picture was perceived as "ingenious" because the children were able to see the truth and express it. It is known that many artists, knowing this reality, have then tried to imitate the child's objectivity, creativity, and simplicity of forms. At the beginning of the $20^{\text {th }}$ century, the children's drawings, which are considered children's art by some of the theorists, were displayed in the prominent cultural centres of Europe. Many masters of fine art openly admitted that they were fascinated by the child's creation. Even Wassily Kandinsky, Pablo Picasso, Paul Klee, Joan Miró, and others were intensively involved in the child's artistic performance. They collected the art and simultaneously exhibited it with their work. In the article, the author seeks a correlation between children's drawings and art schemes, which were used by masters of fine arts of the 20th century. Other topics that the author develops are artistic language and symbolism, schematism, the perception of traditional beauty, and artistic expression, such as the new perception of traditional beauty.
\end{abstract}

Keywords: child's artistic expression, schematism, writing, picture, space, artistic-symbolic code

\section{INTRODUCTION}

Many signs, symbols, diagrams, and metaphors are symptomatic for mythology and its stories, as well as for the art of today. Contemporary art, in many respects, is close to the world of a child's drawing. The reason is 
that it does not attempt the accurate reproduction of phenomena that their authors meet daily. For contemporary artists, there is an importance of reflection, mood, feeling, a materialization of their inner world, which reacts to the world around them. The child, as well, through their symbols, tries to give a reference on themselves, and on what is around them. As the myth portrays the picture of the world through the symbols, also the child communicates with the surrounding environment. $S /$ he tries to give their pictures a certain form of their symbols and depictions, which only the author himself can understand, as it reflects their subjective world. This children's world relates to the transformed nature of the myths, to the fairy tale.

History of fine art and concerning culture document that the child's drawing has always been, and further on remains an inspiration for many masters of fine art (J. Fineberg, 1995). In the era of romanticism, the child's drawing was perceived as ,ingenious" because the children were able to see the truth and express it. It is known that many artists, knowing this reality, have then tried to imitate the child's objectivity, creativity, and simplicity of forms.

At the beginning of the $20^{\text {th }}$ century, the children's drawings, which are considered children's art by some of the theorists, were displayed in the prominent cultural centres of Europe. Many masters of fine art openly admitted that they were fascinated by the child's creation. Even Wassily Kandinsky, Pablo Picasso, Paul Klee, Joan Miró, and others were intensively involved in the child's artistic performance. They collected the art and simultaneously exhibited it with their work.

Modern artists owned collections of children's drawings. Paul Klee as 23 years old, returning from his studies in Rome (1920), in his father's house, found a number of his drawings from his early childhood. They enormously attracted his attention, influenced his further artistic expression to the extent that he started to collect the pictures of his son Felix. Throughout his life, he was involved in the child's artistic expression, was inspired by it, and looked for "the return to the roots" in it. A great collection of the child's drawings was also owned by the artists of the younger generation, e.g. Jean Dubuffet, 22 years younger than Paul Klee, then the members of the COBRA group (formed in 1948) and representatives of pop-art.

Similarly, some other artists enjoyed the returns to the child's drawing. Michail Larionov admired his son and painted his pictures according to his son's drawings. In his creation, he used the expressive dynamics of colour. He interpreted the new method of the disintegration of things to ray-like, rhythmically arranged lines as the inevitable consequence of cubist, futuristic, and orphistic experiments with abstraction. Child's drawings were an endless inspiration for Gabriele Münthe. From the point of semiotics, psychoanalysis, and anthropology, we can find the useful parallels at the level of the child's drawing at already mentioned Wassily Kandinsky, who, apropos, was very much interested in the child's drawing. In his pictures, he essentially used abstraction intending to reduce the volume of materialistic matter. He subtracted from the things, not only their weight but their body measurements - the spatial definition as well. The item itself is meaningless to him; what is accentuated, is his unpredicted motives, emotions which are concretized in the picture as the composed accords of colours and lines. The creative approach is reflected in harmonious compositions of colours and forms mirroring their freedom and stillness of the spirit, emotion, and thinking. Consequently, a free, playful, and spontaneous expression is of concern to children. And precisely this freedom of expression was the object of the search in the art creation of Wassily Kandinsky, also Paul Klee, Pablo Picasso, Joan Miró, and other titans of fine art.

\section{THE WORLD OF CHILDREN'S DRAWING AS AN ART SCHEME}

\section{1. Artistic-symbolic code}

Expressionism tended to emphasize a mental point of view. Work of art was considered the expression of artistic soul, attempting gradation of the expression, even at the cost of deformation. In the effort of underlining the expressive value of the motive, the masters of fine art deformed the forms of a being and a thing until a complete decomposition. This was reflected in the symbolism of lively, relaxed, and bright colouring. The artists created the abstract compositions of forms, and they preferred plane decorative and rhythmic linear elements. In their style-forming tendencies, the authors oriented towards the art of nature nations. This art exaggerated and consequently unified individual forms according to the needs of magic. The similarity in artistic language and orientation towards the child's artistic expression is yet comparative; the reason is that every child's drawing is then also a deformation, highlighting what the child considers essential.

Paul Klee was considerably involved in the research of basic geometric forms and pure linear combinations, derived from expressionism. The drawings are often formed by one continuous line which changes its direction and forms the square and zigzag patterns. The line is formed spontaneously as an abstract pattern, 
to which there are added additional figural elements. He used to say that he „portrayed the line of a walk". In his work, we can often find the roads, sidewalks as metaphors of the artist's interest in creative processes, which exceeded his interest in his final work. „Never try to portray the definite image... Do not think about the final form but about the forming lines", he advised the others (S. Kentová, 1996, p. 58.) His artistic-symbolic code, containing thematic information, resembles the informative code in the children's drawings. The systems of the graphic elements usually determine the shape of objects. All the elements are arranged in a way that each of them has its position and cannot be replaced by anything else. Paul Klee did not leave anything up to the chance event; he always attached great importance to the aesthetic-artistic point.
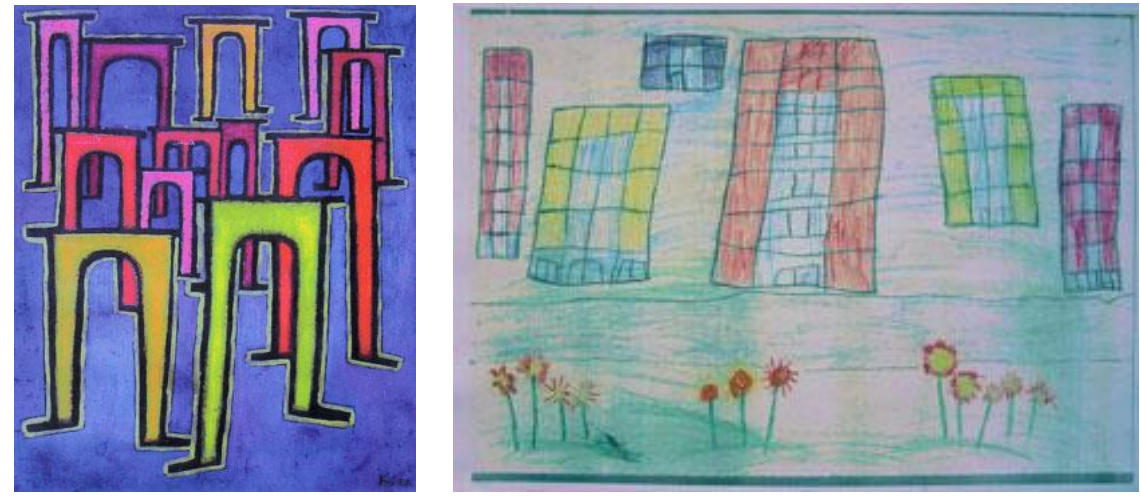

Fig. 1. Paul Klee: „Revolution of the Viaduct" (1937), right „The world I observe", seven year old child

Let's imagine, in the small area, as there gradually is formed a mosaic of colourful squares and rectangles, letting us sense the geometric rule. The lines are neither fully horizontal nor vertical but they "give out" the principle of the vertical or horizontal. The colours are transparent; they are on the move; they live and breathe. The study of the nature of the symbol and comparison enable us to state that Klee's principle resembles one of the children: the children also find out that some of their pictures could also be bearers of some information, e.g. „the circle as an apple", „the rectangle as a car". Paul Klee leans towards the relative; that is why he artistically played so much, artistically explored, and treated the basic and simple forms in a way that is usually and naturally done by children. The similarity of his creation with one of the children is therefore remarkable.

We can find fantastic elements in the work of many artists of the $20^{\text {th }}$ century in the dream and poetic associations of Paul Klee, in the scenes of fairytales of deep, distinct colours painted by Marc Chagall. Viewers' great interest in fantastic themes is documented by many entertaining pieces of work, comics created by illustrators of science fiction, and works of literature. Amongst them are the authors of comics Phillipe Druillet or Jean Giraud, called Moebius. Nowadays, comics are top-rated and in recent years, children have also enjoyed drawing them. They are inspired by contemporary popular art. It is noteworthy that those children who prefer the stories of comics show quite a high level of drawing abilities. However, their performance has only a little in common with traditional artistic expression.

\subsection{Thinking and schematism}

Henri Matisse, a sensitive painter and a supporter of an intensive joy of life, drawing from a philosophy that „... an artist has to look at life with the eyes of a child. Otherwise, s/he loses the possibility to express himself originally". Matisse was confident in the fact that "drawing comes out of the spirit" and that is why he frequently searched, explored, and gradually fulfilled his credo. To receive the definite form, different versions in various stages, which followed one another, were formed. These stages, in an original way, led to increasingly stronger schematization, to intensive and pure colouring. His prudence and schematism led to deliberated deformation supported by composition reduced to a pure and basic line.

Not taking into consideration the naivety in the work of Henri Matisse, in some of his pictures we are attracted by the diversity of colours applied in larger areas, which gave up any relation to the volume. Pure colour, a simple shortcut, the regularities of the composition of the pictorial space without modelling and shading, as well as the perfect harmony between the emotional expression and the decorative composition, are comparable to the regularities of the child's artistic creation. In both cases, they fascinate and captivate us mainly with their simplicity, purity, clarity and a large degree of abstraction. 


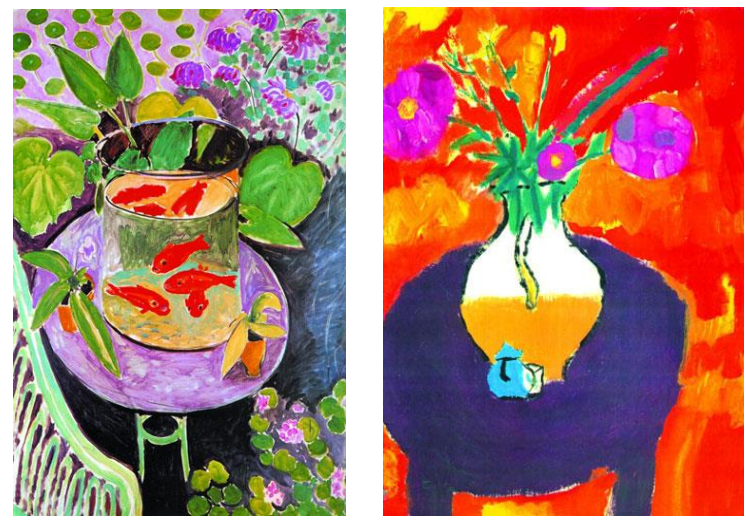

Fig. 2. Henri Matisse: „Goldfish" (1912), right „Vase", eight year old childl

\subsubsection{Playfulness, spontaneity, sincerity, cleanliness, courage and desire for search}

French cubists were the first to draw attention to the aesthetic values of the child's artistic creation. They (after the impressionism which lightened and "aerated" the forms), elevated the colouring and clarified the basics of visual perception, considered it necessary to come back to the line, shape, to the material form of objects, to their relief values. The cubists, since Cézanne and the fauvists instructed them, were interested in portraying the material reality in its full tangibility and objectivity, not as it appeared but realistically. They aimed to place the whole material comprehensiveness of the three-dimensional objects and things onto a two-dimensional canvas.

The conceptual realism, on which the children's drawings are based, also has other peculiar similarities to the effort of the cubists: portraying the same element from many sides, the circle perspective, simultaneous interchanging of the plan and elevation, transparency. In this way, there it comes to disassembling of objects to their parts, whereas we can see them in chronology one after another and from many angles of view. In the picture, these are portrayed simultaneously and next to each other. On the surface, the subject is changed - the still lifes replace the countryside with bottles, glasses, fruit, and a guitar; portraying of space disappeared from the pictures. According to Juan Gris, for Braque, the guitar was the same as Madonna for the medieval artists, or what presence of the Sun, a flower, a tree, or a lamp means for children.

One of the greatest artists of abstraction who used to find the motives in the mythological symbols of the nature nations was Pablo Picasso. This artist was so much attracted by a mythology that he volunteered to illustrate the Metamorphosis of Ovidius where the poet remakes antic mythology. These illustrations serve as evidence of Picasso's ability to express the essence of the depicted idea using simple forms. In the cycle which is abstracting the bull's body, Picasso was able to achieve a pure line, the minimum expressive means in a way that is managed, in their subconscious simplicity, only by children or the primaeval man. Picasso's effort and ability to abstract and simplify was intentional and therefore more difficult, whereas children can abstract without realizing it. The artists of nature nations acted similarly; a lot of heritage of our ancestors endured in their creation. Their artistic performance brings evidence that they drew what they knew about things and not what they saw. The whole sphere of myths is, in fact, about what the people knew about the world and tried to explain the unexplainable using the entire series of symbols and signs. Nowadays, these enable us to understand, at least partially, the way of their thinking.

Pablo Picasso preserved in himself a lot of the child - playfulness, spontaneity, sincerity, cleanliness and courage, desire for search, for the future. With resourcefulness and playfulness, characteristic of him, he resembled a child. Pablo enjoyed performing magic and played with the form and the language of his pictures. He thoroughly explored, experimented, and got to know the reality of our world and human life. He joined the elements of two different specializations of research: cubism, where the object is depicted from different viewpoints simultaneously, and the child's way of portraying, with their great freedom of composition. Not only that he tried to know the world with the eyes of children, they quite often represented an inspiration for him; that is why he used to aptly remark: „All my life I have learned to draw in a way children do".

Children portray things as they know them. The customariness of artistic creation does not burden them; they experiment with a clear mind. They follow their own experience and memories. In doodling and the tangle of lines, they explore geometric shapes and can tell complete stories about them. They can entirely 
comment on the colourful doodling with several ovals and spirals. Thanks to their unbounded fantasy, a square is a house, a circle is the Sun, and a colourful tangle of lines resembles grass. Children use fragmentary signs and symbols instead of concrete objects. Several figures portrayed "through each other", deformations and exaggerated enlargement for better expression of their emotional attachment to the portrayed reality, are typical for a child.

Children's drawings are heartfelt and can present not only the external look of the portrayed reality as they can see it. However, they tend to show what is inside of the object and slightly reveal their inside. The child linearly portrays and at the same time tells you not only how the house, where they live, is big; they also tell you whom they live with, what they like doing, and whom they love the most. As children, even Picasso in his creation was far off any dogma; his effort was to reach the distinct simplifying of outlines and surfaces. He always experimented, and he never followed any theory; he restricted himself to the main shapes and surfaces. In a certain period of his creation, he even abandoned the colourful tones. To give a real picture of his emotions, he restricted his pallet of colours only to several basic ones.

Picasso always looked for new approaches, ways of expression, to be able to portray the object the most accurately. He played with the form. "When I want to paint a bowel, then I naturally show you that it is rounded. However, the general rhythm of the picture, the compositional layout can force me to portray this curve as a square". He disassembled the figures, and then again, he assembled them. In his pictures, we see the things portrayed so realistically, from many available angles and viewpoints using all information about the model, as we then have the impression that they are unrealistic. Pablo Picasso used his peculiar principle of composition. The space of the picture is not organized anymore; it does not undergo the principles of homogeneous central perspective; each object is then reproduced individually, each time from a different angle.

„I treat the painting as I treat the objects; it means that I paint the window in a way I look out of it. If the window looks delusively in the picture, I close it and pull the blind just like I would do so in my room. In fine art, just like in life, it is necessary to act smoothly. Naturally, in fine art, there are also conceptions, and it is important not to overlook them. Yes, there is no other choice. And that is why we have to keep in mind the real-life", he adds on the margin of his artistic performance.

Innumerable experiments are leading towards the natural development of his work of art which brings evidence of Picasso's frankness. He expressed himself very straightforwardly and sincerely, just like a child. He was astonished by everything new, and the old things inspired him to remake them. He explored the new techniques thanks to his curiosity and natural playfulness. He experimented with everything, and he was interested in the original function of an object. Things around him were changing in his hands; they lived the story which the author inscribed in them as the child who makes the animals, let's say from the chestnuts, or it can be their favourite character from the fairytale or a collage. The Baboon with the baby was created similarly - by his son's cars forming his head. All parts composing this artwork are collected in each other, in a way that it is impossible to imagine individual elements separately.

\subsection{Outer world versus the inner world}

Joan Miró is said to embody the notion of "homo ludens", a playful man. He also was the "homo faber", a creative man. Miró naturally met also the signification of the notion „homo sapiens", as a man who enjoyed knowing. He drew his expressive power from the Indian cult drawing of Latin America. However, in his nature, he was a deep thinker. Hardly anybody was able to express his creative process, his intentions, and the commitment of his creation as accurately as Joan Miró. This characteristic but also the customariness of his artistic creation, suggests that he also belongs to the artists who were very close to the child's artistic expression.

Not only history but also current events always influenced his creation. The external and internal world came to mutual unity. Traces of this unity, which surrealism attempted and which originally existed at all people, may be found in the child's artistic expression up to nowadays. A small child does not see the rough contrast between the outer world of life's inevitabilities and the inner world of games and dreams. S/he wants to step into new dimensions, explorations, secrets, yet wants to keep their old imaginations. S/he connects the imaginary to the realistic, a dream to reality, and the objective to the subjective. In this sense, Joan Miró serves the children as an example. His vision helps the children to see what they could not and was not able to see.

Joan Miró was able to preserve the child's mind. As he remarks, he hopes to find „all values of the childhood" at the end of his life. He dared to be unlimitedly creative. In his artistic expression, he was inspired by games, toys, and robots. To the system of surface signs, spatial figures, and writing, he was able to 
compose some mechanical elements, levers. In his creation, he connected reality with the secret in an unrestrained space. As he noted, he was grateful to Dadaists who were creating in the principle of accident, illogical associations, nonsense; this way, they attempted to belittle the existing conventions. They also connected their values with the belief in a new, unmarked world of primary and clean children's emotions.

Just like children, also Joan Miró was inspired by nature; he respected its order. He was particularly interested in organic shapes, their flexibility, and dynamics. Miró created some kind of mythological pictorial signs in which he joined the human, animal, or plant motives; these were then put to some interesting absurd associations. With courage, he used to find the expressive means which were natural and did not tend to astonish: he felt rhythmical, loved curves, especially the spiral. He schematized shapes either to the form of geometric shapes - circles, triangles, and cones, or reduced them to a simple line. In a certain period, he also separated, isolated, and segregated individual parts from the unit as independent forms, and he indicated their compactness only by a connecting line.

Fearlessness, the courage to experiment with colours was input to looking for an analogy with the child's artistic expression. His colours look clear, intensive, clean, bright, even suggestive; just like children's. In his picture world, there are fairytale-looking trees, flowers, even space, the Sun, Moon, and stars. All the objects and things have their characteristic form, which is so close to children. That is why Miró is an artist naturally and effortlessly accepted by children. One of the Mirós interests was to tell, in colours, how he was impressed by the scenery of countries, already portrayed in simple, rough lines using charcoal. In the pictures, we immediately get to know the persistent, creative effort of the author, as well as portraying of seeming reality, also typical for children.

Alongside with not very frequent landscapes portraying the favourite spots, there were the first still lifes announcing their arrival. Mirós pictures are filled with figures which „almost become the grotesque, comic or dramatic figures. They are moving, dancing, yawning. They mirror the author's interior" (M. Bucci, 1972, p. 13). This example is precisely how also children can portray. Miró does not have to speak straightforwardly. The things, figures talk instead of him. „The propelling force and the expressive means of his artistic brushwork is a colour full of energy - the bearer of emotion and state of mind. His red is incandescent, dripping, fleshy, and rarely smutty. The green is inhibited, iron blue, sometimes sour, sprinkled with ice-blue. His blue colours are bright and clean; his ceruse is matt and dull, somehow expressing exhalation and space in the dense tangle of other colours" (M. Bucci, 1972, p. 13).

Children also like this kind of pallet of colours. Clean and chromatic colours attract them. According to eightyear-old Romanko: „Red colour is full of energy, sometimes it is encouraging, sometimes threatening". "Yellow colour is like a sunbeam which penetrates and lights up all corners", also eight-year-old Zuzka added. „Violet colour is like a balance between blue and red. Neither one nor the other can prevail; otherwise, it will not be violet", admits nine-year-old Palko.

Comparison and analysis of the pictures enable us to express the opinion that every lively language, also the language of Joan Miró and the language of children gradually changes. Miró never fixed one sign for one notion. He always found a new one; again and again, he compared the sign and optical perception; he verified the mediated voltage in reduction. Miró created and discovered several artistic synonyms for the triplet of notions: a woman, a bird, and a star. Just like children, he also put some forms aside; other forms stayed permanently valid: the celestial bodies - the Sun, Moon and the stars - which formed Miró's cosmology, signs of the escape ladder formed by four to six crossed lines, a wavy line or a refracted line ended with a circle and finally the spiral coming out of the central point. His creation persuades us that the master of art verified the expressional reservoir of the sign language; he was able to extend it and tell the whole stories these ways. Joan Miró has a lot in common with the child's artistic expression, and that is why, not accidentally, he remarked: „The older I am, and the better I master the creation, the more I turn to my experience from my early childhood. I think that at the end of my life I am going to restore all the strength of my childhood". Eventually, we can illustrate it by the piece called the Moon wall located in Paris, in front of the UNESCO Palace, and by the wall full of signs, symbols, colours, and stories of a 10-year-old boy who hides the message from the far and close past.

Similarly, in the next child's picture, there is the life of ants portrayed. Although the man symbolized by the footprint of his shoe is big and powerful, they can set an example for their diligence. In another child's picture, there is a tennis player who wandered to different places; she sees and hears a lot of interesting: excellent music, a heartbeat, a paved sidewalk, secrets, coloured country, and danger. Herbert Read perceived art as an area full of symbols where some of them substitute images or notions, which from the historical viewpoint, are already settled. However, children's symbols are arbitrary and non-systemic. They do not attempt the translation of the graphic image or the artistic form. These are the objects with image 
associations. The author escapes the vivacity of his images; s/he wants to create something relatively firm and personal $-\mathrm{s} /$ he wants to escape reality. S/he creates a visual symbol, a code in the language of lines which are expressions of the author's emotions (H. Read, 1967).

\subsection{Violating the boundaries of traditional beauty}

A great collection of the child's art is owned by a lot of artists of the younger generation, e.g. Jean Dubuffet, 22 years younger than Paul Klee, the already mentioned members of the COBRA group but also the representatives of pop-art.

Jean Dubuffet's primitivist-genetic figuration also manifests an attitude of Dadaist provocation that goes as far as an absurdity. Furthermore, we find in it surreal automatic irrationalism, which is concretized in the adoration of naively depicted disrespect, the ruthlessness of children and the mentally ill (art brut). Conscious non-artistic treatment of characters that seem trivial, grotesque to absurd, is called „art-brut", i.e. raw art, or art in the raw state. Deliberate non-artistic treatment with the signs which impact trivially, grotesque, and even absurd; he called them „art brut", crude art or art in a natural condition.

Jean Dubuffet, similarly like children, liked the abstract world, the world of fantasy and dreams. That is why he formed a subjective way of expression, which was also the reflection of his mental labyrinth. He usually substituted the signs of primitive figuration by personal mythology. Even today, his paintings fascinate with tactility, bizarre formal figurativeness, which is expressed in spontaneous handwriting, reminiscent of doodles on the grey walls of houses, doodles that we inadvertently walk around on asphalt sidewalks.

For Jean Dubuffet, the material nature of the relief layers was the bearer of the picture plot, of narratives. „My apparatus works like a machine which cuts down the names of things, and demolishes party walls, destroys the meaning distinguishing different things, different systems of things, different groups of facts and things, different levels of thinking" (K. Thomas, 1994, p. 221).

Jean Dubuffet never hid the fact that he had found inspiration in the child's artistic expression. He broke through the boundaries of traditional beauty, and that is why he noted: „... better crude art than cultural art ..." He filed his art as "crude art" of harmless visionaries. He usually pictured not what he saw at the moment, but what Jean would like to see; he ignored the proportions. It is suggested by his figures which look as if they stepped out of the child's drawing.

Jean Dubuffet was an inventor of new forms and radically new language smashing down existing habits in the perception of artistic expression. Whereas the master of art points at primitivist figuration, the child copes with this issue spontaneously. We find traces of pictogram records in his artistic expression. The artwork of the titan of fine art and the child's artistic expression is linked with interesting imprints, the tracks in the sand: „All soil in the oasis, trod in this way and full of tracks and signs, is like a giant sketchbook, the sketchbook with improvisations. Similarly, the school board covered with writing is the ground we live on, perish, and learn" (J. Dubuffet, 1993, p. 189).

Jean Dubuffet was attracted by the naive infantility of a child's drawing and non-sophisticated spontaneity of the artistic expression of ill people. The world of the art of Dubuffet is open to everybody; we can permanently come in, and simultaneously explore it. The world of the child's drawing is identical - open and deep. Similarly to the way, the mentioned artist felt the urgent need to escape the world of reality and move to the world of fantasy; the same way the children, by their drawing, can express their secret world. Their expression is a subjective issue, similarly to Jean Dubuffet. Every point on the canvas or in the paper is a message, a code which we have to learn how to read. Also, in a child's artistic creation, we discover the picture of their playful and dreamy micro-world fascinated by the diversity of the real world. The master of an art, similarly to children, did everything with love and also at a quick pace. He enjoyed the positive result of each work which a bit topped his strengths and possibilities. Therefore, he used to say about his artwork that "he does not want his work to be perceived as the one created by an exceptional hand, but the hand of anybody else" (J. Dubuffet, 1993, p. 18). He ignored proportions, and he oriented his attempts to portray the things towards the graphic concept impossible to describe. His work was a far cry from the real, objective criteria; so many people used to speak about his creation as about the one of a child. „This is the approach I am concerned with - to see them (the objects) and not to gaze at them too much and not to pay more attention to them than an ordinary person would pay it in a normal life", Jean Dubuffet added (J. Dubuffet, 1993, p. 199).

\subsection{Influencing children's perceptions}

The artist of pop-art Andy Warhol and David Hockney, with their attitude to advertisement and media, shifted 
the relation of our thinking from nature to "culture" which in the rudiments also influences the child's perceptions (D. Hockney, A cruel elephant). According to A. Warhol, the pop-art "wants to give the floor to the things themselves". Everydayness becomes aesthetic and beautiful through advertisement, comics, graffiti, fashion, and design. "Superficiality" of everyday look is overcome by stylization and indirect transformation, multiplying and enlarging, which transform the object of everyday use to the artwork having its place in the museums and galleries.

A. Warhol was the first one who made art out of documents and banal quotations from everyday life. He showed that everything becomes a creation when it is adequately reproduced. Andy multiplied the most primitive drawings, wrappings of the most popular products, and broadly famous faces. He proved that the value of reproduced works could reach the number of unique pieces of work. It is necessary to an ad that over 300 of his pictures (by the subject and size) were dedicated exclusively to children. The toys inspired him from Hongkong, China, and Russia. In his pictures, we could see a lot of multicoloured children's mechanical toys, e.g. Pando - the teddy bear, dogs, monkeys, or cars. All of them were placed in the Children's gallery in Swiss Zurich and Warsaw as low as the children could visually perceive them.

\subsection{Child's artistic expression transposed to artistic creation}

Francesco Clemente incorporated a child's drawing of his children to the mouth of a giant head in his picture. He repeated and transformed similar procedures many times. A less noticeable way of incorporating the child's drawings to his picture was used by Donald Baechler, who used several different child's drawings in his picture named Balzac in 1989.

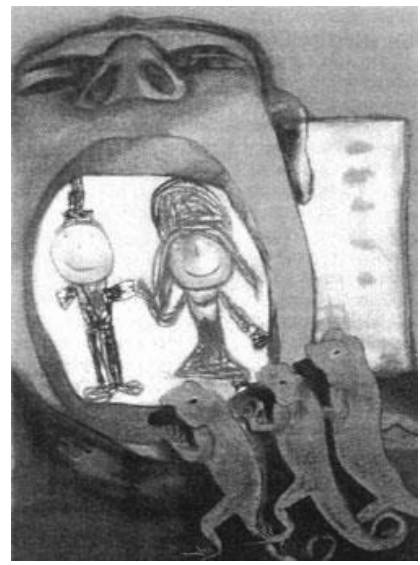

Fig. 3. Francesco Clemente: „Untitled" (1985)

\subsection{Children as co-authors and co-creators}

Methods of Keith Haring and Jean-Michel Basquiat seem odd. They deployed children as helpers, assistants to help at work with their pictures. Jasper Johns was confident that the process of children's cognition itself had many links with art. The reason is that in the little child's drawing, the crucial role is played by the unintentional, development conditioned "conventions" (J. Fineberg, 1995). He discovered these formalities in his artwork Flags and numerals from the 50-ties. Their use, including „prefabricated" forms, gave him new possibilities for personal expression and emotional self-validation. In his creation, an important role is played by the child's drawings, which he incorporated into a number of his pictures. This transformation of expression in John's creation forms a distinct contrast to the existential model of abstract expressionism. It points at the new concept of individuality connected to multimedia and virtual reality.

\section{CONCLUSION}

It is evident that representatives of modern art forms have broken the barrier of conservative art and proved the endlessness of art and the boundlessness of artistic beauty. They connected the random character with the principle of constructive, artistic intent which can have an enormous effect either on the artist's canvas or in the child's paper, perhaps from a blot that accidentally dripped from the brush. Even though the personal experience, cultural awareness, or the way of artistic reflection of the artist and the child vary, they also have a lot in common. The text, and above all, the individual pictures persuade us that the elementary qualities of artistic expression are principally comparable. Artistic (sign) means, principles of art creation, the abstract 
and the concrete foreshadow the perception of the visual art of nowadays.

Children's artistic expression is no longer just a presentation of what their authors know or see in their surroundings. It is more important to know that artistic expression is tied to a system of symbols. Children discover and create a different system(s) of symbols, which also allow them to express their vision of the world. Their graphic logic predominates in their work, and children acquire the ability to use graphic language at an early age. At the same time, they develop different possibilities of expression and at the same time, different visual language. Even later, children use geometric shapes, use „old" forms in their work and gradually introduce newer ones. These are graphic symbols, with their specific qualities and competencies, including different expressions between drawing and other genres of visual representation. Children's artistic expression is still accompanied by movement, sound, gesture, spoken word. If children understand the priorities or limitations, i.e. the possibilities of different art genres, they basically have a repertoire of signs and symbols to visually record everyday reality or their own imagination.

Children's artistic expression is significantly influenced today in a diverse and dynamically changing social and cultural environment, which includes completely new, hitherto unknown qualities, such as multi-culture, multimedia environment, technological development, globalization. The current process of children's visual imagination must, therefore, be seen as a reflection of a civilized society, which is in an unprecedented dynamic process of change. It is more than evident that the children's world will not be an isolated world, immune to civilization paradigms. Children will sensitively perceive it, influence it and shape it. Therefore, their artistic expression will take on new forms, forms and content expression. Our research confirms that children do not resist these changes.

On the contrary, they gradually use new means of expression, changing the content and the way they are displayed. Just as their artistic expression is influenced by the environment and on different levels, so it is diverse and multifaceted. It is difficult today to talk about precisely defined developmental concepts of children's artistic expression. On the ontogenetic principle, the linearly conceived concept of the development of pictorial creation already seems to be insufficient and obsolete at present. For the time being, the understanding of children's artistic expression is more acceptable than the notion of „open structure", as children simultaneously develop various possibilities of expression and the same time visual language. This is the reason why we should examine it as a phenomenon and pay increased attention to it in the future as well.

\section{REFERENCE LIST}

Arnheim, R. (1974). Art and visual Perception. Berkeley - Los Angelos, 1974.

Arnheim, R. (1992). Entropie a umění. Praha, 1992.

Bremmer, J., Moore, S. (1984). Prior visual inspection and object naming: Two factors that enhance hidden feature inclusion in young children's drawings. In British Journal of Developmental Psychology, 2, pp. 371-376.

Brittain, W. L. (1979). Creativity, art, and the young child. New York : MacMillan, 1979.

Bucci, M. (1972). Joan Miró. Bratislava : Pallas, 1972.

Clark, A. B. (1997). The child's attitude toward perspective problem. In Studies in Education.

Cox, M. (1981). One thing behind another: Problems of representation in children's drawings. Educational Psychology, 1(4), pp. 275-286.

Čapek, J. (1996). Uměni prírodních národů. Praha : DAUPHIN.

Darras, B. (1996). Au commencement etait l'image: Du dessin de l'enfant a la communication de l'adulte. Paris : ESF.

Darras, B., Kindler A. M. (1996). Morphogenese et teleology des images. Imagies, 1, pp. 49-56.

Darras, B., Kindler, A. M. (1966). Morphogenese et teleology des images et de l'imagerie initiale. In B. Darras, Au commencement etait l'image: Du dessin de l'enfant a la communication de l'adulte. Paris : ESF, pp. 73-94. 
Dubuffet, J. (1991). Pariž : ADAGP.

Eco, U. (2004). Meze interpretace. Praha : Karolinum.

Eco, U. (2001). Mysl a smysl. Sémiotický pohled na svět. Praha : Svoboda, 1995 (2000).

Freeman, N. H. (1980). Strategies of reprezentation in young children. New York.

Golomb, C. (1992). The child's creation of a pictorial world. Berkeley : University of California Press.

Goodman, N. (2007). Jazyky umění. Nástin teorie symbolů. Praha : Academia.

Goodenough, F. L. 1926. Measurement of intelligence by drawings. New Yor : Harcourt, Brace and World.

Kellogg, R. (1969). Analyzing children's art. Palo Anto : National Press Books.

Kentová, S. (1996). Umenie zblízka. Kompozícia. Bratislava : Parfekt.

Kindler, A. M. (2000). Drawing development through the lenses of age and culture. Paper presented at the 30th Annual Meeting of the Jean Piaget Society. Montreal : Canada.

Kindler, A. M., Darras, B. 1998. Culture and development of pictorial repertoires. In Studies in Art Education, 39(2), pp. 47-67.

Kindler, A. M. (Eds). (1997). Child development in art. Reston : NAEA, p. 183-192.

Klee, P. (1990). Čáry. Praha : ODEON.

Klee, P. (1999). Pedagogický náčrtník. Praha : Triáda.

Klee, P. (2000). Vzpomínky, deníky, eseje. Praha : Arbor Vitae.

Korzenik, D. (1977). Saying it with pictures. In D. Perkins and D. Leonard (Eds.) The arts and cognition. Baltimore : John Hopkins University Press.

Löwenfeld, V. (1947). Creative and mental growth. New York : Macmillan.

Luquet, G. H. (1927). Le dessin enfantin. Paris : F. Alcan.

Maletová, R. M. (1986). Joan Miró. Praha : Odeon.

Miler, Ž. E. (1963). Paul Klee. Figure i maske. Belehrad.

Pariser, D. (1997). Graphic development in artistically exceptional children. In A. M. Kindler (Eds). Child development in art. Reston : NAEA, pp. 115-130.

Piaget, J. (1950). The psychology of intelligence. New York : Harcourt Brace.

Piaget, J (1954). The construction of reality in the child. New York : Basic Books.

Piaget, J., Inhelder, B. (1956). The child's conception of space. London : Routledge and Kegan Paul.

Pijoan, J. (1977 -1987). Dejiny umenia I-X. Bratislava : Tatran.

Read, H. (1964). Osudy moderního uměni. Praha : Odeon.

Reed, H. (2002). Mezi myšlenkou a vyjádřením. Praha : Herman a synové.

Schmalennbach, W. (1968). Paul Klee. Obrazy, kresby akvarely. Düsseldorf.

Stefano, L. (1996). Pablo Picasso. Praha : SVOJTKA a VAŠUT.

Šupšáková, B. (2009). Child's creative expression through fine art. Ljubljana : DEBORA.

Šupšáková, B. (2013). Detský výtvarný prejav: od čmáraníc k obrazom a ich významom. Bratislava : DOLIS.

Šupšáková, B. (2015). Vizuálna gramotnost'. Brno : Tribun EU.

Thomasová, K. (1994). Dejiny výtvarných štýlov 20. storočia. Bratislava : PALLAS.

Vygotský, L. S. (1981). Psychológie uměni. Praha : SPN.

Walther, I. F. (1992). Pablo Picasso. Berlín.

Willats, J. (1997). Art and representation. Princeton : Princeton University Press. 